\title{
Effect of balanced concentrate ration on the performance and hematobiochemical profile of lactating native ewes and lambs in coastal Odisha
}

\author{
Sasanka Sekhar Beura ${ }^{1}$, Chitta Ranjan Pradhan ${ }^{1}$, Bhagirathi Panigrahi ${ }^{1}$, Chiranjib Sahoo ${ }^{1}$, Abhishek Sahoo ${ }^{2}$ and \\ Biswadeep Jena ${ }^{3}$
}

\begin{abstract}
1. Department of Livestock Production and Management, College of Veterinary Science and Animal Husbandry, Orissa University of Agriculture and Technology, Bhubaneswar, Odisha, India; 2. Department of Animal Nutrition, College of Veterinary Science and Animal Husbandry, Orissa University of Agriculture and Technology, Bhubaneswar, Odisha, India; 3. Department of Veterinary Surgery and Radiology, College of Veterinary Science and Animal Husbandry, Orissa University of Agriculture and Technology, Bhubaneswar, Odisha, India.
\end{abstract}

Corresponding author: Sasanka Sekhar Beura, e-mail: sasankavet41@gmail.com,

CRP: pradhancr@gmail.com, BP: bpanigrahi65@yahoo.co.in, CS: chiranjib_sahoo2050@yahoo.co.in, AS: draviseq@gmail.com, BJ : biswadeep44@gmail.com

Received: 06-08-2014, Revised: 08-11-2014, Accepted: 11-11-2014, Published online: 08-12-2014

doi: 10.14202/vetworld.2014.1047-1057. How to cite this article: Beura SS, Pradhan CR, Panigrahi B, Sahoo C, Sahoo A, J ena B (2014) Effect of balanced concentrate ration on the performance and hematobiochemical profile of lactating native ewes and lambs in coastal Odisha, Veterinary World 7(12): 1047-1057.

\begin{abstract}
Aim: The present study was conducted to evaluate the effect of supplementation of balanced concentrate ration during lactation on the growth performance, blood and metabolic profiles of native ewes and lambs in coastal Odisha.

Materials and Methods: A total of 40 numbers of lactating ewes of the same parity comprised the experimental animals. The selected ewes were randomly assigned to two groups of twenty each, maintaining uniformity in body weight (13.36 $\pm 0.33 \mathrm{~kg}$ for Group 1 and 13.48 $\pm 0.37 \mathrm{~kg}$ for Group 2). Group 1 was maintained on grazing only while Group 2 was supplemented with a balanced concentrate mixture @ 200 g/head/day during the first 2 months of lactation. The concentrate was fed individually in separate containers in the morning hours before the animals were taken out for grazing.

Results: The ewes in Group 2 registered higher body weights at every fortnight. The differences were found to be highly significant $(\mathrm{p}<0.01)$ from $2^{\text {nd }}$ to $5^{\text {th }}$ fortnight and significant $(\mathrm{p}<0.05)$ for the remaining fortnights. The ewes in Group 2 showed significantly $(\mathrm{p}<0.01)$ higher daily gains than those in Group 1 at every fortnight. The hemoglobin (Hb) concentration, mean cell hemoglobin $(\mathrm{MCH})$ and total leukocyte count $(\mathrm{TLC})$ values were significant $(\mathrm{p}<0.05)$ between groups at the end of $4^{\text {th }}$ fortnight after lambing and the mean cell hemoglobin concentration (MCHC) values is significantly $(p<0.05)$ higher in Group 2 over Group 1.
\end{abstract}

Conclusion: It was concluded that supplementation of a balanced concentrate mixture (crude protein 18.21\%) @ 200 g/ewe/day along with grazing during the first 2 months of lactation resulted in higher ewe body weight gain. It improved their hematological and metabolic profiles and also resulted in higher body weight gain in lambs born to these supplemented ewes.

Keywords: body weight, concentrate, ewe, lamb, Odisha

\section{Introduction}

Sheep is an important species of livestock in India contributing greatly to food, fibre, rural employment and gross domestic products, and it is of special economic importance in arid, semi-arid and hilly areas. It plays an important role in the rural economy and is principally maintained by poorer section of the rural community providing them a source of livelihood. Out of total sheep found in Odisha, only two breeds of sheep i.e., Ganjam and Bolangir have been identified and reported both by FAO and ICAR. Ganjam sheep constitute a total of $25.21 \%$, Bolangir sheep $19.88 \%$ and the remaining $54.91 \%$ are considered as nondescript. These nondescript sheep include Kuzi/Deshi/Kendrapara, Koraput, Edka, Dalua [1].

Copyright: The authors. This article is an open access article licensed under the terms of the Creative Commons Attributin License (http:// creative commons.org/licenses/by/2.0) which permits unrestricted use, distribution and reproduction in any medium, provided the work is properly cited.
These sheep are named according to their place of origin or distribution or phenotypic characters shown by them. The Deshi or Kuzi or Kendrapara sheep is primarily a mutton breed distributed in large numbers in coastal districts of Odisha like Puri, Jagatsinghpur, Cuttack and Kendrapara. Kuzi sheep is characterized by its small adult body weight (18-22 kg). Kuzi sheep found close to the sea coast are dwarf. Higher body weights were recorded for Kuzi sheep in undivided Cuttack district, especially in Jagatsinghpur region and called as Desi. As the Kuzi or Kendrapara sheep are only maintained on community rangelands, they often face feed scarcity due to low forage yield with wide seasonal variations and higher stocking density of animals. It results in decreased dry matter intake and nutrient utilization pattern in grazing sheep even to meet the maintenance requirements, preventing them to express their full production potential and affects the profitability of sheep rearing for farmers. The dietary supplementation is high during lactation 
due to increased nutrient requirement for milk production. Maternal nutrition, particularly during lactation has a bearing on the body condition of the ewe which, in turn, influences milk yield, mortality rate during early part of growth and body weight gain in lambs, conditions which are so very crucial on economic aspects of sheep rearing. It is observed that the challenge in feeding lactating ewes is to provide adequate energy and protein to support milk production for proper growth of its lambs. To minimize the stress due to milk secretion during lactation, high-quality feed ingredients should be fed to the ewes during this period. Moreover, Coop [2] reported that the nutritive level of the ewe during lactation had more effect on lamb growth than nutritive level during pregnancy. A low cost scientific input as concentrate supplementation at the rate of $1 \%$ of body weight to ewes during this critical stage is recommended to enhance their production performance, general condition as well as growth rate of lambs [3].

The present study is proposed to be undertaken with the objectives to study the effects of a balanced concentrate supplement to ewes in early lactation on ewe performance i.e., body weight, hematobiochemical profile, postpartum onset of estrus and lamb performance i.e., body weight gain together with incidence of diseases and mortality.

\section{Materials and Methods}

\section{Ethical approval}

The experiment followed the guidelines of Institutional Animal Ethics Committee.

\section{Study area}

The experiment was conducted on lactating ewes reared by the farmers of Mundida village in Tirtol block of Jagatsinghpur district, which is located in tropical wet eastern part of Odisha, lies between $19^{\circ}$ $58^{\prime} \mathrm{N}$ and $20^{\circ} 24^{\prime} \mathrm{N}$ latitude, $86^{\circ} 02^{\prime} \mathrm{E}$ and $86^{\circ} 43^{\prime} \mathrm{E}$ longitude, covering a landmass of $1,759 \mathrm{sq} . \mathrm{km}$.

\section{Animals}

The experimental animals comprised forty numbers of lactating ewes of same parity (20 belongs to 1 st lactation and rest 20 belongs to $2^{\text {nd }}$ lactation) of similar body weight (average $13.42 \mathrm{~kg}$ ) selected from the flocks of four farmers of this village. The ewes selected before parturition were identified with neck tags and were then fed with concentrate just after parturition. The selected ewes were randomly assigned to two groups of 20 each, maintaining uniformity in body weight and parity. 40 lactating ewes were randomly divided into two groups of 20 each. Of the 20 ewes in each group, 10 ewes were in first, and other 10 were in second parity. The ewes in both groups were dewormed at the beginning of the experiment with albendazole @10mg/kg body weight. The lambs were dewormed at the end of the $1^{\text {st }}$ fortnight and subsequently at monthly intervals with piperazine hexahydrate@ 200 mg/kg body weight.

\section{Feeding protocols}

Group 1 was maintained solely on grazing and Group 2 was provided with a balanced concentrate supplement, as shown in Table-1, at the rate of $200 \mathrm{~g} / \mathrm{head} /$ day during the first 2 months of lactation along with grazing. The supplemental feeding was done individually in separate containers in the morning hours before the animals were taken out for grazing.

\section{Recording of individual body weight}

Individual body weight of the ewes in each group was recorded at the beginning of the experiment (at lambing) followed by fortnightly intervals for a period of 13 fortnights (182 days). Body weight was recorded with the help of a spring balance of $25 \mathrm{~kg}$ capacity ( $0.1 \mathrm{~kg}$ least count). Birth weights of individual lamb for the two groups were recorded soon after birth before feeding colostrums. Birth weight was recorded with the help of electronic single pan balance of $5 \mathrm{~kg}$ capacity (0.01 kg least count). Subsequently, individual body weights of lambs under each group were recorded at fortnightly intervals from birth to the $13^{\text {th }}$ fortnight of age. The experimental animals were weighed in the morning before offering feed and water, with the help of a spring balance of $25 \mathrm{~kg}$ capacity ( $0.1 \mathrm{~kg}$ least count).

\section{Evaluation of haematobiochemical parameters}

Blood samples were collected from six ewes from each group, at the beginning of the experiment, i.e., just after lambing, $4^{\text {th }}$ fortnight after lambing and $12^{\text {th }}$ fortnight after lambing. Blood samples were collected in the morning prior to feeding and watering. These samples are subjected to estimations of hematological parameters like hemoglobin $(\mathrm{Hb})$ (g/dL), hematocrit or packed cell volume (PCV) \%, total erythrocyte count (TEC) $10 \% \mu \mathrm{L}$, mean corpuscular volume (MCV) fL, mean corpuscular hemoglobin $(\mathrm{MCH}) \mathrm{pg}$, mean corpuscular hemoglobin

Table-1: Ingredients and nutrient composition (\%) of the concentrate mixture.

\begin{tabular}{lc}
\hline Ingredients & Quantity in kg \\
\hline Crushed maize & 42 \\
Soyabean cake & 11 \\
Sesame oil cake & 10 \\
De-oiled rice bran & 34 \\
Mineral mixture & 02 \\
Common salt & 01 \\
\hline Nutrient composition & $\%$ \\
\hline DM & 92.74 \\
Crude protein & 18.21 \\
Ash & 6.37 \\
Ether extract & 5.28 \\
Crude fibre & 6.16 \\
NFE* & 56.72 \\
ME, MJ/kg DM & 12.74 \\
\hline
\end{tabular}

*Calculated, "Calculated from table values of energy content of the components, NFE=Nitrogen free extract, $\mathrm{ME}=$ Metabolisable energy, $\mathrm{MJ}=$ Megajoules, $\mathrm{DM}=$ Dry matter 
concentration (MCHC) g/dL and total leukocyte count (TLC) per $\mu \mathrm{L}$; along with estimations of biochemical parameters like glucose $(\mathrm{mg} / \mathrm{dL})$, total protein $(\mathrm{g} /$ $\mathrm{dL}$ ), albumin (g/dL), globulin (g/dL), cholesterol (mg/ $\mathrm{dL}$ ), urea (mg \%), creatinine (mg/dL), serum glutamic pyruvic transaminase (SGPT) alanine aminotransferase (ALT) (Units/L), alkaline phosphatase (ALP) (Units/L), serum glutamic oxaloacetic transaminase (SGOT), aspartate transaminase (AST) (Units/L) and total calcium (mg/dL)

\section{Statistical analysis}

The data from the experiment were subjected to statistical analysis as per the methods suggested by Snedecor and Cochran [4].

\section{Result}

\section{Ewe body weight and average daily gain}

The mean fortnightly body weights for the ewes in the two groups are presented in Figure-1. For the ewes in Group 1, the body weight showed a slight depression at the first fortnight, which was followed by a steady increase at every fortnight till the end of the $13^{\text {th }}$ fortnight (182 days). For the ewes in Group-2, the body weight showed an increase with successive fortnights till the $4^{\text {th }}$ fortnight and remained almost constant with erratic trends till the end of $7^{\text {th }}$ fortnight. Thereafter, it went on increasing through successive fortnights up until the end of the $13^{\text {th }}$ fortnight. The ewes in Group 2 registered higher body weight at every fortnight. The differences were found to be highly significant $(\mathrm{p}<0.01)$ from $2^{\text {nd }}$ to $5^{\text {th }}$ fortnight and significant $(\mathrm{p}<0.05)$ for the remaining fortnights.

The ewes in Group 1 exhibited a loss in daily weight gain during the $1^{\text {st }}$ and $2^{\text {nd }}$ fortnights. Thereafter the daily gain increased progressively from $3^{\text {rd }}$ to the $13^{\text {th }}$ fortnight. The ewes in Group 2 showed an increase in daily gain from $25.36 \pm 1.78 \mathrm{~g} /$ day at the $1^{\text {st }}$ fortnight to $52.02 \pm 4.42 \mathrm{~g} /$ day at $3^{\text {rd }}$ fortnight, after which the daily gain decreased gradually till $8^{\text {th }}$ fortnight and remained almost constant with fluctuating

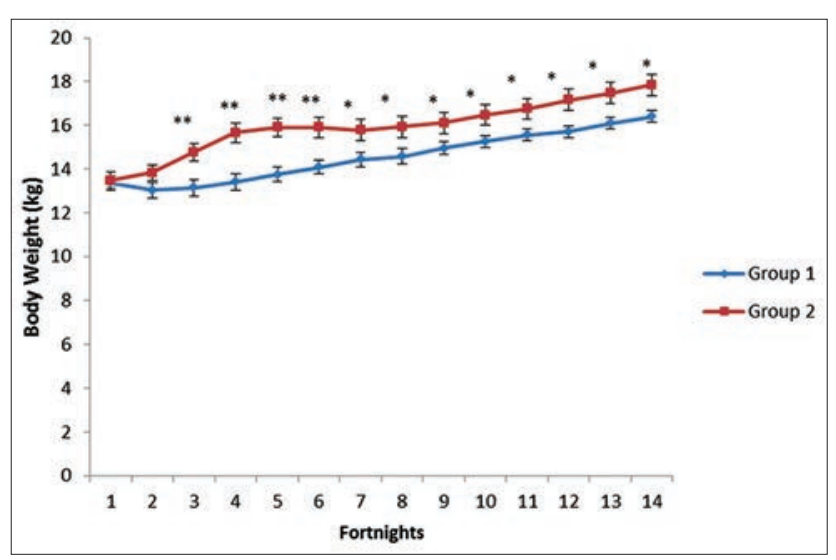

Figure-1: Mean \pm standard error values of fortnightly body weight of ewes of different groups. * Significantly different from the base value $(p<0.05)$. ** Significantly different from the base value $(p<0.01)$. trends till $13^{\text {th }}$ fortnight. The ewes in Group 2 showed significantly $(\mathrm{p}<0.01)$ higher daily weight gains than those in Group 1 at every fortnight.

\section{Hematological profiles in ewes}

The means of Hb concentration, PCV or hematocrit, TEC, MCV, mean corpuscular $\mathrm{Hb}$ or $\mathrm{MCH}$, MCHC and TLC for the ewes in the two treatment groups are presented in Table- 2 .

\section{Haemoglobin $(\mathrm{Hb})$}

The Hb concentrations recorded were $9.38 \pm 0.47$ and $9.29 \pm 0.58 \mathrm{~g} / \mathrm{dL}$ for ewes in Group 1 and Group 2, respectively at lambing. There was no significant difference between these two values at the start of the experiment. At the end of 4th fortnight after lambing, the $\mathrm{Hb}$ concentrations recorded were $8.12 \pm 0.78$ and $9.13 \pm 0.67 \mathrm{~g} / \mathrm{dL}$ for Group 1 and Group 2, respectively. At the end of 12th fortnight after lambing, the $\mathrm{Hb}$ concentrations recorded were $9.22 \pm 0.78$ and $9.43 \pm 0.62 \mathrm{~g} / \mathrm{dL}$ for Group 1 and Group 2, respectively, there being no significant ( $\mathrm{p} \geq 0.05$ ) difference between the groups.

\section{Packed cell volume (PCV)}

The PCV values recorded for the two groups of ewes were $28.97 \pm 1.13$ and $30.23 \pm 1.41 \%$ for Group 1 and Group 2, respectively at lambing and no significant difference $(\mathrm{p} \geq 0.05)$ was found between these two values at the start of experiment. At the end of the 4th fortnight after lambing, the PCV values recorded were $24.18 \pm 1.57$ and $28.42 \pm 1.28 \%$ for Group 1 and Group 2, respectively. This value of PCV for Group 2 was significantly $(\mathrm{p}<0.05)$ higher than that of Group 1. At the end of the $12^{\text {th }}$ fortnight after lambing, the PCV values recorded were $29.18 \pm 1.51$ and 31.42 \pm 1.19 for Group 1 and Group 2, respectively. The PCV values were higher for the lambs in Group 2 at the end of $4^{\text {th }}$ and $12^{\text {th }}$ fortnight, and the differences were also significant $(\mathrm{p}<0.05)$ at both the stages.

\section{Total erythrocyte count (TEC)}

The TEC values recorded at start of the experiment, i.e., immediately after parturition were $10.12 \pm 0.32$ and $10.20 \pm 0.49 \times 10^{6} / \mathrm{mm}^{3}$ for the ewes in Group 1 and Group 2, respectively. At the end of $4^{\text {th }}$ fortnight after lambing, the TEC values recorded were $10.23 \pm 0.63$ and $10.51 \pm 0.41 \times 10^{6} / \mathrm{mm}^{3}$ for Group 1 and Group 2, respectively. At the end of the $12^{\text {th }}$ fortnight after lambing, the TEC values recorded were $10.43 \pm 0.60$ and $10.83 \pm 0.34 \times 10^{6} / \mathrm{mm}^{3}$ for Group 1 and Group 2, respectively. The TEC values at both the stages, tended to be higher for the lambs in Group 2, however the differences were non-significant ( $\mathrm{p} \geq 0.05$ ).

\section{Mean corpuscular volume (MCV)}

The MCV values of ewes recorded at lambing were 28.68 \pm 0.97 and 29.74 $\pm 1.01 \mathrm{fL}$ for Group 1 and 
Table-2: Haematological profiles in ewe

\begin{tabular}{|c|c|c|c|c|c|c|}
\hline \multirow[t]{2}{*}{ Parameters } & \multicolumn{2}{|c|}{ At lambing } & \multicolumn{2}{|c|}{$4^{\text {th }}$ fortnight } & \multicolumn{2}{|c|}{$12^{\text {th }}$ fortnight } \\
\hline & Group 1 & Group 2 & Group 1 & Group 2 & Group 1 & Group 2 \\
\hline $\mathrm{Hb}(\mathrm{g} / \mathrm{dL})$ & $9.38 \pm 0.47$ & $9.29 \pm 0.58$ & $8.12^{\mathrm{a}} \pm 0.78$ & $9.13^{b} \pm 0.67$ & $9.22 \pm 0.78$ & $9.43 \pm 0.62$ \\
\hline Haematocrit (PCV) (\%) & $28.97 \pm 1.13$ & $30.23 \pm 1.41$ & $24.18^{\mathrm{a}} \pm 1.57$ & $28.42^{b} \pm 1.28$ & $29.18^{\mathrm{a}} \pm 1.51$ & $31.42^{b} \pm 1.19$ \\
\hline $\operatorname{TEC}(106 / \mu \mathrm{L})$ & $10.12 \pm 0.32$ & $10.20 \pm 0.49$ & $10.23 \pm 0.63$ & $10.51 \pm 0.41$ & $10.43 \pm 0.60$ & $10.83 \pm 0.34$ \\
\hline$M C V(f L)$ & $28.68 \pm 0.97$ & $29.74 \pm 1.01$ & $23.65^{\mathrm{a}} \pm 0.87$ & $27.04^{b} \pm 1.13$ & $27.98^{a} \pm 0.82$ & $29.01^{b} \pm 1.08$ \\
\hline $\mathrm{MCH}(\mathrm{pg})$ & $9.31 \pm 0.50$ & $9.07 \pm 0.67$ & $7.98^{\mathrm{a}} \pm 0.61$ & $8.71^{\mathrm{b}} \pm 0.67$ & $8.84 \pm 0.54$ & $8.72 \pm 0.58$ \\
\hline $\mathrm{MCHC}(\mathrm{g} / \mathrm{dL})$ & $32.27 \pm 2.68$ & $30.58 \pm 2.04$ & $33.59 \pm 2.18$ & $32.13 \pm 2.13$ & $31.59^{\mathrm{a}} \pm 2.11$ & $30.02^{b} \pm 2.01$ \\
\hline TLC (per $\mu \mathrm{L})$ & $7953 \pm 121$ & $8105 \pm 118$ & $7752^{a} \pm 116$ & $7858^{b} \pm 143$ & $8118 \pm 126$ & $7994 \pm 134$ \\
\hline
\end{tabular}

a,bMeans in a row bearing different superscripts differ significantly $(p<0.05), M C H=$ Mean cell hemoglobin, $M C H C=$ Mean cell hemoglobin concentration TLC $=$ Total leukocyte count, TEC $=$ Total erythrocyte count, $M C V=$ Mean corpuscular volume, $\mathrm{PCV}=$ Packed cell volume, $\mathrm{Hb}=$ Haemoglobin

Group 2, respectively, and there was no significant difference ( $\mathrm{p} \geq 0.05$ ) between the two groups at lambing. At the end of $4^{\text {th }}$ fortnight after lambing, the MCV values recorded were $23.65 \pm 0.87$ and $27.04 \pm 1.13 \mathrm{fL}$ for Group 1 and Group 2, respectively. The MCV value for Group 2 was significantly $(\mathrm{p}<0.05)$ higher than that of Group 1 . At the end of $12^{\text {th }}$ fortnight after lambing, the MCV values recorded were $27.98 \pm 0.82 \mathrm{fL}$ and 29.01 \pm 1.08 fL for Group 1 and Group 2, respectively, which also showed significant $(\mathrm{p}<0.05)$ difference between the groups.

\section{Mean corpuscular haemoglobin (MCH)}

The MCH values recorded just after parturition were $9.31 \pm 0.50$ and $9.07 \pm 0.67 \mathrm{pg}$ for the ewes in Group 1 and Group 2, respectively. The MCH values at different stages showed fluctuation in its value i.e., $7.98 \pm 0.61$ and $8.71 \pm 0.67 \mathrm{pg}$ at the end of $4^{\text {th }}$ fortnight and $8.84 \pm 0.54$ and $8.72 \pm 0.58 \mathrm{pg}$ at the end of $12^{\text {th }}$ fortnight for Group 1 and Group 2, respectively. The differences in the values of $\mathrm{MCH}$ were significant $(p<0.05)$ between group 1 and 2 only at $4^{\text {th }}$ fortnight in favor of Group 2.

\section{Mean corpuscular haemoglobin concentration (MCHC)}

The MCHC values recorded just after parturition were $32.27 \pm 2.68$ and $30.58 \pm 2.04 \mathrm{~g} / \mathrm{dL}$ for the ewes in Group 1 and Group 2, respectively. The MCHC values at different stages showed fluctuation in its value i.e., $33.59 \pm 2.18$ and $32.13 \pm 2.13 \mathrm{~g} / \mathrm{dL}$ at the end of $4^{\text {th }}$ fortnight and $31.59 \pm 2.11$ and $30.02 \pm 2.01 \mathrm{~g} / \mathrm{dL}$ at the end of $12^{\text {th }}$ fortnight for Group 1 and Group 2, respectively. The differences in the values of MCHC were significant $(p<0.05)$ between Group 1 and 2 only at $12^{\text {th }}$ fortnight in favor of group.

\section{Total leukocyte count (TLC)}

The TLCs recorded just after parturition were $7953 \pm 121$ and $8105 \pm 118 / \mu \mathrm{L}$ of blood and at the end of $4^{\text {th }}$ fortnight $7752 \pm 116$ and $7858 \pm 143 / \mu \mathrm{L}$ for Group 1 and 2 respectively. The ewes in Group 2 had significantly $(p<0.05)$ higher leukocyte count than the ewes in Group 1 . At the end of the $12^{\text {th }}$ fortnight after lambing, the TLC values recorded were $8118 \pm 126$ and $7994 \pm 134 / \mu \mathrm{L}$ for Group 1 and Group 2, respectively, showing no significance ( $\mathrm{p} \geq 0.05)$ between the groups.

\section{Serum biochemical profiles in ewes}

The means of serum glucose $(\mathrm{mg} / \mathrm{dL})$, total protein (g/dL), albumin (g/dL), globulin (g/dL), albumin/globulin ratio, cholesterol (mg/dL), urea (mg \%), creatinine (mg/dL), SGPT (ALT) (U/L), ALP (U/L), SGOT (AST) (U/L), calcium total (mg/ $\mathrm{dL}$ ) for the ewes in the two groups are presented in Table-3.

\section{Glucose}

The mean serum glucose concentrations recorded at lambing were $51.43 \pm 1.76$ and $52.05 \pm 1.46 \mathrm{mg} / \mathrm{dL}$ for the ewes in Group 1 and Group 2, respectively. At the end of 4th fortnight, the serum glucose levels in the ewes of Group $2(53.13 \pm 1.62 \mathrm{mg} / \mathrm{dL})$ were significantly $(\mathrm{p}<0.05)$ higher than that of Group 1 $(48.37 \pm 1.51 \mathrm{mg} / \mathrm{dL})$. At the end of the 12th fortnight, the values were $50.83 \pm 1.51$ and $51.03 \pm 1.63 \mathrm{mg} / \mathrm{dL}$ for Group 1 and 2 respectively. Though the value was higher for Group 2 over Group 1, it was found non-significant ( $\mathrm{p} \geq 0.05)$.

\section{Total protein}

The serum total protein levels in ewes immediately after lambing were $8.43 \pm 0.65$ and $8.52 \pm 0.44 \mathrm{~g} / \mathrm{dL}$ for Group 1 and Group 2, respectively with no significant difference $(\mathrm{p} \geq 0.05)$. At the end of 4th fortnight, the values were found to be $6.85 \pm 0.46$ and $7.86 \pm 0.37 \mathrm{~g} / \mathrm{dL}$, indicating a depression in serum total protein. The ewes in group 2 showed significantly $(\mathrm{p}<0.05)$ higher concentrations than those in Group 1 at the end of 4th week after lambing. The total protein values for the Group 1 and 2 at the end of $12^{\text {th }}$ week after lambing were found to be $7.89 \pm 0.48$ and $7.98 \pm 0.41 \mathrm{~g} / \mathrm{dL}$ respectively, showing no significant difference $(\mathrm{p} \geq 0.05)$ between the groups.

\section{Albumin}

The serum albumin concentrations recorded were $4.62 \pm 0.17$ and $4.73 \pm 0.12 \mathrm{~g} / \mathrm{dL}$ for the ewes in Group 1 and Group 2, respectively at lambing. For Group 1 and Group 2, respectively, the value recorded was $4.59 \pm 0.21$ and $4.69 \pm 0.19 \mathrm{~g} / \mathrm{dL}$ at the end of 
Table-3: Serum biochemical profiles in ewe.

\begin{tabular}{|c|c|c|c|c|c|c|}
\hline \multirow[t]{2}{*}{ Parameters } & \multicolumn{2}{|c|}{ At lambing } & \multicolumn{2}{|c|}{$4^{\text {th }}$ fortnight } & \multicolumn{2}{|c|}{$12^{\text {th }}$ fortnight } \\
\hline & Group 1 & Group 2 & Group 1 & Group 2 & Group 1 & Group 2 \\
\hline Glucose (mg/dL) & $51.43 \pm 1.76$ & $52.05 \pm 1.46$ & $48.37^{\mathrm{a}} \pm 1.51$ & $53.13^{b} \pm 1.62$ & $50.83 \pm 1.51$ & $51.03 \pm 1.63$ \\
\hline Total protein $(\mathrm{g} / \mathrm{dL})$ & $8.43 \pm 0.65$ & $8.52 \pm 0.44$ & $6.85^{\mathrm{a}} \pm 0.46$ & $7.86^{b} \pm 0.37$ & $7.89 \pm 0.48$ & $7.98 \pm 0.41$ \\
\hline Albumin ( $g / d L)$ & $4.62 \pm 0.17$ & $4.73 \pm 0.12$ & $4.59 \pm 0.21$ & $4.69 \pm 0.19$ & $4.59 \pm 0.28$ & $4.69 \pm 0.21$ \\
\hline Globulin $(\mathrm{g} / \mathrm{dL})$ & $3.81 \pm 0.51$ & $3.79 \pm 0.53$ & $2.26^{a} \pm 0.45$ & $3.17^{b} \pm 0.32$ & $3.30 \pm 0.48$ & $3.29 \pm 0.34$ \\
\hline Cholesterol ( $\mathrm{mg} / \mathrm{dL})$ & $46.98 \pm 1.49$ & $46.77 \pm 1.91$ & $45.76^{\mathrm{a}} \pm 1.03$ & $52.19^{b} \pm 0.83$ & $44.98^{\mathrm{a}} \pm 1.03$ & $49.19^{b} \pm 0.78$ \\
\hline Urea (mg \%) & $53.47 \pm 1.45$ & $54.12 \pm 1.19$ & $54.35^{\mathrm{a}} \pm 1.32$ & $58.42^{\mathrm{b}} \pm 1.13$ & $54.05^{\mathrm{a}} \pm 1.02$ & $56.72^{\mathrm{b}} \pm 1.10$ \\
\hline Creatinine $(\mathrm{mg} / \mathrm{dL})$ & $0.76 \pm 0.14$ & $0.70 \pm 0.09$ & $0.94 \pm 0.08$ & $0.82 \pm 0.06$ & $0.88 \pm 0.08$ & $0.84 \pm 0.10$ \\
\hline SGPT (ALT) (units/L) & $41.82 \pm 0.79$ & $42.21 \pm 0.72$ & $40.62 \pm 0.69$ & $42.00 \pm 0.78$ & $41.72 \pm 0.67$ & $42.10 \pm 0.72$ \\
\hline ALP (units/L) & $159.33 \pm 1.85$ & $160.27 \pm 1.29$ & $153.93 \pm 1.85$ & $158.27 \pm 1.17$ & $159.93 \pm 1.45$ & $162.47 \pm 1.13$ \\
\hline SGOT (AST) (units/L) & $109.65 \pm 1.47$ & $108.98 \pm 1.41$ & $113.65 \pm 1.27$ & $114.98 \pm 1.41$ & $107.85 \pm 1.14$ & $110.78 \pm 1.21$ \\
\hline Calcium, total ( $\mathrm{mg} / \mathrm{dL}$ ) & $10.35 \pm 0.54$ & $10.67 \pm 0.38$ & $10.45 \pm 0.51$ & $10.69 \pm 0.39$ & $10.65 \pm 0.48$ & $10.70 \pm 0.34$ \\
\hline
\end{tabular}

a,b Means in a row bearing different superscripts differ significantly $(p<0.05)$, SGPT=Serum glutamic pyruvic transaminase, $\mathrm{ALT}=\mathrm{Alanine}$ aminotransferase, $\mathrm{ALP}=$ Alkaline phosphatase, $\mathrm{SGOT}=\mathrm{Serum}$ glutamic oxaloacetic transaminase, AST=aspartate transaminase

$4^{\text {th }}$ fortnight and $4.59 \pm 0.28$ and $4.69 \pm 0.21 \mathrm{~g} / \mathrm{dL}$ at the end of the $12^{\text {th }}$ fortnight.

\section{Globulin}

The serum globulin concentrations recorded were $3.81 \pm 0.51$ and $3.79 \pm 0.53 \mathrm{~g} / \mathrm{dL}$ for the ewes in Group 1 and Group 2, respectively, at lambing. At the end of $4^{\text {th }}$ fortnight after lambing, the values recorded were $2.26 \pm 0.45$ and $3.17 \pm 0.32 \mathrm{~g} / \mathrm{dL}$ for Group 1 and Group 2, respectively and on $12^{\text {th }}$ fortnight it was found to be $3.30 \pm 0.48$ and $3.29 \pm 0.34 \mathrm{~g} / \mathrm{dL}$ respectively, which showed that the value for Group 2 on $4^{\text {th }}$ fortnight was significantly $(\mathrm{p}<0.05)$ higher than that of Group 1.

\section{Total cholesterol}

The mean serum total cholesterol levels found just after lambing were $46.98 \pm 1.49$ and $46.77 \pm 1.91 \mathrm{mg} / \mathrm{dL}$ for the ewes in Group 1 and Group 2, respectively. At the end of $4^{\text {th }}$ fortnight the values recorded were $45.76 \pm 1.03$ and $52.19 \pm 0.83 \mathrm{mg} / \mathrm{dL}$ and on $12^{\text {th }}$ fortnight it was $44.98 \pm 1.03$ and $49.19 \pm 0.78 \mathrm{mg} / \mathrm{dL}$ for the ewes in Group 1 and Group 2, respectively, which shows the serum cholesterol of Group 2 is significantly $(\mathrm{p}<0.05)$ higher than Group 1.

Urea

The serum urea recorded for Group 1 ewes were $53.47 \pm 1.45,54.35 \pm 1.32$ and $54.05 \pm 1.02 \mathrm{mg} \%$ at lambing, on $4^{\text {th }}$ fortnight and $12^{\text {th }}$ fortnight respectively and that for Group 2 were $54.12 \pm 1.19,58.42 \pm 1.13$ and $56.72 \pm 1.10 \mathrm{mg} \%$ respectively. These values showed that there were significant $(\mathrm{p}<0.05)$ differences between Group 1 and 2 at $4^{\text {th }}$ and $12^{\text {th }}$ fortnight.

\section{Creatinine}

The serum creatinine recorded for Group 1 ewes were $0.76 \pm 0.14,0.94 \pm 0.08$ and $0.88 \pm 0.08 \mathrm{mg} / \mathrm{dL}$ at lambing, on $4^{\text {th }}$ fortnight and $12^{\text {th }}$ fortnight respectively and that for Group 2 were $0.70 \pm 0.09,0.82 \pm 0.06$ and $0.84 \pm 0.10 \mathrm{mg} / \mathrm{dL}$ respectively. There was no significant difference between the values for Group 1 and 2 at any stage.

\section{SGPT (ALT)}

The SGPT values recorded for Group 1 ewes were $41.82 \pm 0.79, \quad 40.62 \pm 0.69$ and $41.72 \pm 0.67$ $\mathrm{U} / \mathrm{L}$ at lambing, on $4^{\text {th }}$ fortnight and $12^{\text {th }}$ fortnight respectively and that for Group 2 were $42.21 \pm 0.72$, $42.00 \pm 0.78$ and $42.10 \pm 0.72 \mathrm{U} / \mathrm{L}$ respectively. There was no significant difference between the values for Group 1 and 2 at any stage.

\section{ALP}

The ALP values recorded for Group 1 ewes were $159.33 \pm 1.85,153.93 \pm 1.85$ and $159.93 \pm 1.45 \mathrm{U} / \mathrm{L}$ at lambing, on 4th fortnight and 12th fortnight respectively and that for Group 2 were $160.27 \pm 1.29$, $158.27 \pm 1.17$ and $162.47 \pm 1.13 \mathrm{U} / \mathrm{L}$ respectively.

\section{SGOT (AST)}

The SGOT (AST) values recorded for Group 1 ewes were $109.65 \pm 1.47,113.65 \pm 1.27$ and $107.85 \pm 1.14 \mathrm{U} / \mathrm{L}$ at lambing, on $4^{\text {th }}$ fortnight and $12^{\text {th }}$ fortnight respectively and that for Group 2 were $108.98 \pm 1.41,114.98 \pm 1.41$ and $110.78 \pm 1.21 \mathrm{U} / \mathrm{L}$, respectively.

\section{Calcium}

The total serum calcium values recorded for Group 1 ewes were $10.35 \pm 0.54,10.45 \pm 0.51$ and $10.65 \pm 0.48 \mathrm{mg} / \mathrm{dL}$ at lambing, on $4^{\text {th }}$ fortnight and $12^{\text {th }}$ fortnight respectively and that for Group 2 were $10.67 \pm 0.38, \quad 10.69 \pm 0.39$ and $10.70 \pm 0.34 \mathrm{mg} / \mathrm{dL}$ respectively.

\section{Post-partum onset of estrus}

The mean days to postpartum onset of estrus recorded were $68.54 \pm 0.72$ and $64.32 \pm 0.67$ days for the ewes in Groups 1 and 2, respectively. No significant difference was noticed between the groups even as the ewes in Group 2 tended to have a slightly shorter period.

\section{Lamb body weight and average daily gain}

The mean body weights of lambs, measured at fortnightly intervals, for the two groups, are presented in Figure-3. In the case of male lambs, the body weight 


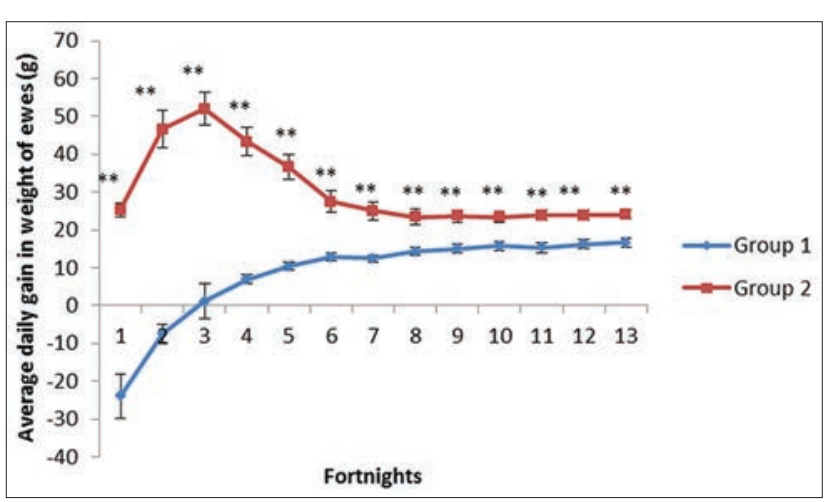

Figure-2: Mean \pm standard error values of fortnightly average daily gain in weight of ewes of different groups. * Significantly different from the base value $(p<0.05)$. $* *$ Significantly different from the base value $(p<0.01)$.

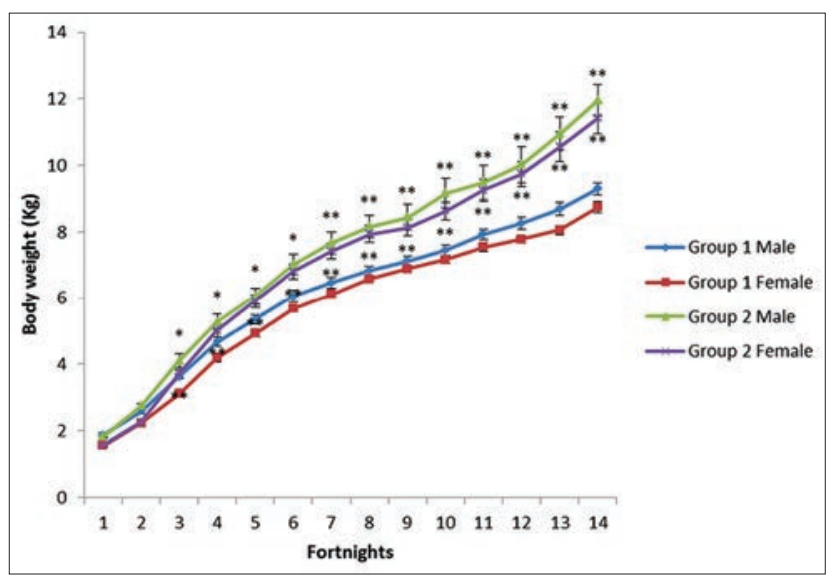

Figure-3: Mean \pm standard error values of body weight of lambs at fortnight intervals of different groups. * Significantly different from the base value $(p<0.05)$. $* *$ Significantly different from the base value $(p<0.01)$.

for Group 1 increased from $1.87 \pm 0.07 \mathrm{~kg}$ at birth to $9.30 \pm 0.18 \mathrm{~kg}$ at $13^{\text {th }}$ fortnight, while for Group 2, it increased from $1.83 \pm 0.04 \mathrm{~kg}$ at birth to $11.95 \pm 0.47 \mathrm{~kg}$ at $13^{\text {th }}$ fortnight (182 days) of age. Similarly, in the case of female lambs, the body weight for Group 1 increased from $1.56 \pm 0.06 \mathrm{~kg}$ at birth to $8.74 \pm 0.17 \mathrm{~kg}$ at $13^{\text {th }}$ fortnight, while for Group 2, it increased from $1.57 \pm 0.04 \mathrm{~kg}$ at birth to $11.42 \pm 0.47 \mathrm{~kg}$ at the age of $13^{\text {th }}$ fortnight.

Initially both for male and female lambs, the birth weight did not significantly differ between Group 1 and Group 2. After that, the lambs in Group 2 registered significantly higher body weights than those in Group 1 during every fortnight. The differences in body weight of male lambs between the groups were found significant $(\mathrm{p}<0.05)$ from $2^{\text {nd }}$ to $5^{\text {th }}$ fortnight, while from $6^{\text {th }}$ to $13^{\text {th }}$ fortnight it was found to be highly significant $(\mathrm{p}<0.01)$. The female lambs in Group 2 registered higher body weights than those in Group 1 at every stage from $2^{\text {nd }}$ to the $13^{\text {th }}$ fortnight, and the differences between the groups were found highly significant $(\mathrm{p}<0.01)$.

The mean cumulative average daily gains in weight at fortnightly intervals for the two groups of lambs are presented in Figure-4. In the case of male

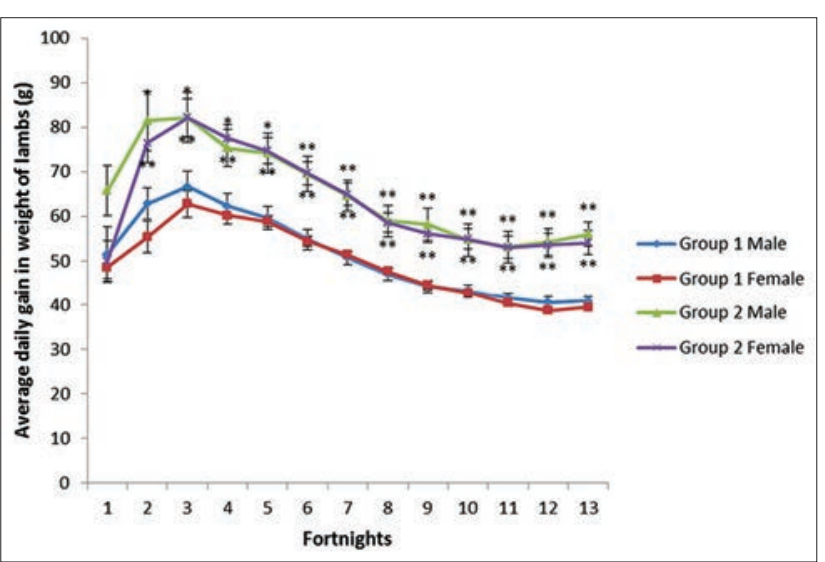

Figure-4: Mean \pm standard error values of fortnightly average daily gain in weight of lambs of different groups. *Significantly different from the base value $(p<0.05)$. $* *$ Significantly different from the base value $(p<0.01)$.

lambs, the daily gains, for Groups 1 and 2, respectively averaged $51.43 \pm 6.19$ and $65.71 \pm 5.61 \mathrm{~g} /$ day at 1 st fortnight, which increased to $66.67 \pm 3.51$ and $82.14 \pm 5.61$ $\mathrm{g} /$ day at $3^{\text {rd }}$ fortnight. After this, the gains gradually declined to $40.82 \pm 1.09$ and $55.99 \pm 2.74$ g/day at the end of the $13^{\text {th }}$ fortnight for Group 1 and 2 respectively with slight fluctuation at last 3 fortnights. The fortnightly average daily gain in body weight of male lambs was significantly $(\mathrm{p}<0.05)$ higher from $2^{\text {nd }}$ to $5^{\text {th }}$ fortnight and after that it was found to be highly significant $(\mathrm{p}<0.01)$ till the end of $13^{\text {th }}$ fortnight.

In the case of female lambs, the daily gains, for Groups 1 and 2, averaged 48.57 \pm 2.56 and $50.00 \pm 4.52 \mathrm{~g} /$ day respectively at 1 st fortnight, which increased to $60.18 \pm 1.94$ and $77.50 \pm 3.04 \mathrm{~g} /$ day at $4^{\text {th }}$ fortnight. After this, the gains gradually decreased to $39.45 \pm 0.95$ and $54.12 \pm 2.64 \mathrm{~g} /$ day at the end of the $13^{\text {th }}$ fortnight for Group 1 and 2 respectively with slight fluctuation at last 2 fortnights. The fortnightly average daily gain in body weight of female lambs was higher $(\mathrm{p}<0.01)$ for lambs of Group 2 from $2^{\text {nd }}$ till the end of the $13^{\text {th }}$ fortnight.

\section{Hematological profiles in lambs}

A shown in Table-4, values of Hb, PCV, MCV and $\mathrm{MCH}$ in lambs showed a significant $(\mathrm{p}<0.05)$ rise in Group 2 as compared to Group 1 during $12^{\text {th }}$ fortnight of age. On the other hand, values of TEC and MCHC showed a rise in Group 2 as compared to Group 1 during $12^{\text {th }}$ fortnight of age, but not significant $(\mathrm{p}<0.05)$ in nature.

\section{Serum biochemical profiles in Lambs}

A shown in Table-5, values of Glucose and cholesterol in lambs showed a significant $(\mathrm{p}<0.05)$ rise in Group 2 as compared to Group 1 during $12^{\text {th }}$ fortnight of age. On the other hand, values of the rest of the biochemical parameters of Group 2 lambs showed a non-significant increase trend in their values.

\section{Incidence of disease and mortality}

No disease or mortality was encountered in either group during the experimental period. 
Table 4: Haematological profiles in lamb

\begin{tabular}{|c|c|c|c|c|}
\hline \multirow[t]{2}{*}{ Parameters } & \multicolumn{2}{|c|}{$2^{\text {nd }}$ fortnight } & \multicolumn{2}{|c|}{$12^{\text {th }}$ fortnight } \\
\hline & Group 1 & Group 2 & Group 1 & Group 2 \\
\hline Haemoglobin (g/dL) & $7.59 \pm 0.38$ & $7.67 \pm 0.28$ & $8.01^{\mathrm{a}} \pm 0.36$ & $8.87^{b} \pm 0.27$ \\
\hline Haematocrit (PCV \%) & $24.32 \pm 1.49$ & $24.71 \pm 1.37$ & $25.43^{\mathrm{a}} \pm 1.39$ & $27.43^{b} \pm 1.31$ \\
\hline $\operatorname{TEC}\left(10^{6} / \mu \mathrm{L}\right)$ & $9.54 \pm 0.37$ & $9.73 \pm 0.57$ & $9.71 \pm 0.34$ & $9.93 \pm 0.59$ \\
\hline $\mathrm{MCV}(\mathrm{fL})$ & $25.49 \pm 0.42$ & $25.41 \pm 0.76$ & $26.67^{a} \pm 0.39$ & $28.19^{b} \pm 0.66$ \\
\hline $\mathrm{MCH}(p g)$ & $7.98 \pm 0.26$ & $7.90 \pm 0.19$ & $8.40^{\mathrm{a}} \pm 0.29$ & $9.12^{b} \pm 0.13$ \\
\hline $\mathrm{MCHC}(\mathrm{g} / \mathrm{dL})$ & $31.21 \pm 1.22$ & $31.04 \pm 1.45$ & $31.50 \pm 1.13$ & $33.84 \pm 1.34$ \\
\hline TLC (per $\mu \mathrm{L})$ & $8226 \pm 119$ & $8292 \pm 168$ & $8534 \pm 128$ & $8456 \pm 159$ \\
\hline
\end{tabular}

a,bMeans in a row bearing different superscripts differ significantly $(p<0.05), M C H=$ Mean cell haemoglobin, $M C H C=$ Mean cell haemoglobin concentration TLC $=$ Total leukocyte count, $\mathrm{TEC}=$ Total erythrocyte count, $\mathrm{MCV}=\mathrm{Mean}$ corpuscular volume, $\mathrm{PCV}=$ Packed cell volume, $\mathrm{Hb}=$ Haemoglobin

Table 5: Serum biochemical profiles in lamb

\begin{tabular}{|c|c|c|c|c|}
\hline \multirow[t]{2}{*}{ Parameters } & \multicolumn{2}{|c|}{$2^{\text {nd }}$ fortnight } & \multicolumn{2}{|c|}{$12^{\text {th }}$ fortnight } \\
\hline & Group 1 & Group 2 & Group 1 & Group 2 \\
\hline Glucose (mg/dL) & $47.34 \pm 1.60$ & $47.63 \pm 1.61$ & $48.47^{\mathrm{a}} \pm 1.43$ & $52.64^{\mathrm{b}} \pm 1.57$ \\
\hline Total protein $(\mathrm{g} / \mathrm{dL})$ & $6.58 \pm 0.29$ & $6.71 \pm 0.31$ & $6.88 \pm 0.29$ & $7.09 \pm 0.36$ \\
\hline Albumin $(\mathrm{g} / \mathrm{dL})$ & $3.76 \pm 0.28$ & $3.81 \pm 0.21$ & $3.79 \pm 0.26$ & $3.85 \pm 0.20$ \\
\hline Globulin $(\mathrm{g} / \mathrm{dL})$ & $2.83 \pm 0.12$ & $2.91 \pm 0.17$ & $3.09 \pm 0.11$ & $3.24 \pm 0.16$ \\
\hline Cholesterol (mg/dL) & $61.39 \pm 1.09$ & $61.48 \pm 1.19$ & $62.99^{\mathrm{a}} \pm 1.13$ & $64.89^{\mathrm{b}} \pm 1.09$ \\
\hline Urea $(\mathrm{mg} \%)$ & $56.07 \pm 1.39$ & $55.89 \pm 1.31$ & $58.37 \pm 1.37$ & $59.19 \pm 1.28$ \\
\hline Creatinine $(\mathrm{mg} / \mathrm{dL})$ & $1.02 \pm 0.09$ & $0.95 \pm 0.06$ & $1.22 \pm 0.08$ & $1.05 \pm 0.06$ \\
\hline SGPT (ALT) (units/L) & $32.76 \pm 0.78$ & $32.84 \pm 0.46$ & $34.76 \pm 0.89$ & $35.84 \pm 0.48$ \\
\hline ALP (units/L) & $167.70 \pm 2.35$ & $168.12 \pm 2.21$ & $168.70 \pm 2.42$ & $172.12 \pm 2.13$ \\
\hline SGOT (AST) (units/L) & $136.72 \pm 1.79$ & $137.08 \pm 2.01$ & $146.72 \pm 1.57$ & $149.08 \pm 1.89$ \\
\hline Calcium, total (mg/dL) & $8.93 \pm 0.71$ & $8.86 \pm 0.68$ & $9.07 \pm 0.69$ & $9.21 \pm 0.68$ \\
\hline
\end{tabular}

a,b Means in a row bearing different superscripts differ significantly $(p<0.05)$, SGPT=Serum glutamic pyruvic transaminase, $\mathrm{ALT}=$ Alanine aminotransferase, $\mathrm{ALP}=$ Alkaline phosphatase, $\mathrm{SGOT}=$ Serum glutamic oxaloacetic transaminase, AST=aspartate transaminase

\section{Discussion}

\section{Ewe body weight and average daily gain}

In the case of ewes in Group 1, the initial depression in fortnightly body weight gain as well as average daily gain might be due to lactation stress on lambing, which the animals could gradually overcome as the milk production might have declined after about 4 weeks of lactation. This finding is in line with the findings of Idris et al. [5] and Adrian and Arancon, [6] who reported that supplementation of ewes during early lactation had significant effect body weight change, as animals do not get enough nutrient requirements to meet mammary growth and milk production. Ewes in Group 1 might have mobilized their reserve more than ewes in Group 2. Also, Idris et al. [5], Tibin et al. [7] and Adrian and Arancon [6] reported that, protein supplementation to ewes grazing low quality pasture improved their body weight. It is reported that the total digestible nutrients requirement of lactating ewes increased during lactation [8]. Jordan and Hanke [9] also reported that the milk production during first 4 weeks of lactation was partially at the expense of stored body tissue. In the case of ewes in Group 2, there was no initial depression in body weight or daily gain, unlike in the case of Group 1 . This might be because of concentrate supplementation to the ewes in this group, which could have helped these ewes to overcome the stress inflicted due to pregnancy and lactation. This finding is in accordance with that of Osuagwah and Aire [10] and Chaturvedi et al. [3]. However, there was a decline in average daily gain from $4^{\text {th }}$ fortnight onwards, since the concentrate was discontinued by the end of 4th fortnight.

\section{Hematological profiles in ewes}

\section{Haemoglobin $(\mathrm{Hb})$}

The significantly higher values $(p<0.05)$ recorded for the ewes in Group 2 might be due to better availability of nutrients from the concentrates for erythrocyte production and $\mathrm{Hb}$ synthesis. Erythropoiesis was affected by the level of feeding in sheep $[11,12]$. The Hb values obtained in the present study were well within the range reported by different workers for sheep. The values reported were; 9.0-14.5 g/100 ml [13] and 8.6-15.8 g/100 ml [14].

\section{Packed cell volume (PCV)}

The PCV values are relevant parameters in the demonstration of the protein state of the ruminants [12], signifies animals of Group 2 has better plane of nutrition. The PCV values in the present study were well within the range, i.e., 22-39\% [14]. However, the values obtained were found lower than that reported (33-46\%) by [13], which might be due to differences in breed, environment, nutrition and health status of the animals in the two studies. 
Total erythrocyte count (TEC)

Decline in the number of red blood cell in the blood of ewes in the early lactation are similar to those of Opara et al., [15]; Skotnicka [16] in goats. The TEC values recorded in the present study were within the range of $6.2-15.5 \times 10^{6} / \mathrm{mm}^{3}$ as reported by Holman [14], 8.5-13.5 $\times 10^{6} / \mathrm{mm}^{3}$ by Coffin [14] and 8.0-16.0 by Schalm [17].

\section{Mean corpuscular volume (MCV)}

The values recorded in the present study were found well within the normal range: 23-48 fL [18], 28-40 fL [19].

\section{Mean corpuscular haemoglobin (MCH)}

All these values recorded in the present study were found well within the normal range: 8-12 [19], while at lower side with respect to the range (9-13) given by Benjamin [18], which may be due to differences in environment and nutritional status of the test animals.

\section{Mean corpuscular haemoglobin concentration (MCHC)}

The MCHC values recorded in the present study were found well within the reported normal range 29-35 g/dL [18], 31-34 g/dL [19].

\section{Total leukocyte count (TLC)}

The TLC values recorded in the present study agreed to the normal value of $4-12.0 \times 10^{3} / \mathrm{mm}^{3}$ ) as reported by Schalm [17] for sheep. The values recorded in the present study were found at par with that reported for Tuj sheep $\left(7.7 \pm 1.9 \times 10^{3} / \mathrm{mm}^{3}\right)$ by Bozdogan et al. [20]. The minute difference between the leukocyte numbers found in the present study and as reported by Bozdogan et al. [20] might be due to differences in breed, environment, nutrition and health status of the animals in the two studies. The TLC observed in the present study are also at par with the reported normal values for adult sheep: $7.62 \times 10^{3} / \mathrm{mm}^{3}$ [21], which substantiates our findings, but lower than $9.2 \times 10^{3} / \mathrm{mm}^{3}$, as recorded by Holman [14]. The increased number of TLC at parturition, and early lactation is probably a response to uterine involution that agrees with those in does [22].

\section{Serum biochemical profiles in ewes}

\section{Glucose}

The significantly higher glucose concentrations during $4^{\text {th }}$ fortnight in Group 2 ewes might be due to the effect of supplementary concentrate feeding. A depressed blood glucose concentration was found in lactating ewes, due to increased utilization of glucose for milk lactose synthesis to maintain blood glucose homeostasis $[23,24]$. There is always an elevated glucose need which consequently increases the glucose turnover during late pregnancy and subsequent stages of lactation [25]. The current study is consistent with earlier results in lactating ewes [26].
The glucose concentrations recorded in the present study conformed to the standard biochemical values in sheep serum as reported by Rodosttis et al. [19].

\section{Total protein}

Usually, the pregnant ewes showed higher concentrations of total protein and albumin in blood when compared to the lactating ewes [27] which might be due to rapid extraction of immunoglobulin from the plasma protein for the colostrum synthesis in the mammary gland. The ewes in Group 2 showed significantly $(p<0.05)$ higher concentrations than those in Group 1 at the end of $4^{\text {th }}$ week after lambing, which could be attributed to their higher plane of nutrition due to supplementary concentrate feeding.

The concentrations found in the present study were within the range or slightly above the range of reported values for sheep Kaneko et al., [28] and Schalm et al. [17]. The overall differences found between the two studies might be due to differences in breed, environment and nutritional status of the animals.

\section{Albumin}

The concentrations recorded in the present study were above the range (2.4-3.0 g/dL) as reported by Rodosttis et al. [19].

\section{Globulin}

The significantly higher globulin value during $4^{\text {th }}$ fortnight in Group 2 ewes might be due to the higher plane of nutrition in this group. The globulin concentrations recorded in the present study were well within the physiological range of 3.5-5.7 $\mathrm{g} / \mathrm{dL}$ as reported by Kaneko [28].

\section{Total cholesterol}

Decreased cholesterol concentrations in early lactation are consistent with an increased energy requirement and negative energy balance which might be due to the influence of the concentrate supplementation. Similar results have been detected by Eshratkhah et al. [29]. The total cholesterol concentrations recorded in the present study are close to the standard values of $52-76 \mathrm{mg} / \mathrm{dL}$ for sheep serum as reported by Benjamin [18].

\section{Urea}

Greater urea concentration in lactating ewes can be due to muscle protein catabolism when large amounts of body reserves are mobilized to fulfill the demand that depends upon body condition score and body weights of the lactating ewes. Jalilian et al. [30] concluded that ewes with lower body condition score have greater urea concentration. Similar results have obtained by Fibrosas and Condiciones [31].

\section{Creatinine}

No significance difference in creatinine values signifies absence of any adverse effects of feed on hepatic function or by the urea cycle [32-34]. 
SGPT (ALT)

The SGPT (ALT) level recorded in the present study is higher than the standard value: 22-38 U/L [19], which may be attributed to the differences in breed, environment, nutrition and health status of the animals.

ALP

There was no significant difference between the values for Group 1 and 2 at any stage, and the values were well within the standard range: 70-390 U/L [19].

\section{SGOT (AST)}

There was no significant difference between the values for Group 1 and 2 at any stage and values obtained were within the standard range: $60-280 \mathrm{U} / \mathrm{L}$ [19].

\section{Calcium}

There was no significant difference between the values for Group 1 and 2 at any stage. The serum calcium concentrations recorded in the present study were slightly lower than the standard value: $11.5-13 \mathrm{mg} / \mathrm{dL}$ [19], which might be due to the requirements for calcium were suddenly raised during the last days of prepartum and the 1st days postpartum as a result of high calcium level in colostrum and milk.

\section{Post-partum onset of estrus}

Sejian et al., [35] opined that prolonged restriction of dietary energy lengthened postpartum estrus period in cattle and sheep, possibly by suppression of the increase in LH pulse frequency that was necessary for growth of ovarian follicles to the pre-ovulatory stage. The findings in the present study agree to some extent to the observations made by Naqvi et al., [36] which showed that by providing supplemental nutrition to pasture grazing ewes for 14 days before lambing and 21 days postpartum, the time to postpartum estrus was shorter, though non-significant ( $\mathrm{p} \geq 0.10$ ) for the supplemented group during dry season (46.9 \pm 2.7 vs. $52.9 \pm 2.6$ day), while in wet season, it was significantly $(\mathrm{p}<0.07)$ shorter for the supplemented group (33.0 \pm 3.1 vs. $41.1 \pm 2.9$ day).

\section{Lamb body weight and average daily gain}

The body weights of lambs recorded in the present study are close to the findings of Parhi et al. [37], who reported 3-month body weight of male and female lambs as $6.980 \pm 0.084$ and $6.563 \pm 0.059 \mathrm{~kg}$ and 6 month body weight as $14.944 \pm 0.124$ and $13.933 \pm 0.073 \mathrm{~kg}$, respectively.

The increased body weight and average daily weight gain for the lambs in Group 2 might be attributed to the supplementary concentrate fed to their dams during lactation, which might have resulted in increased milk production of the dams, leading to higher growth of lambs. This corroborates the findings of Jordan and Hanke [9] and Galvani et al., [38], who reported higher lamb body weight gain when their dams were supplemented with concentrate. Several reports suggest that concentrate supplement increases the milk yield of lactating animals and subsequently increase infant live weight gain like ewes [5,39-41], goat does [42-44].

\section{Haematological profiles in lambs}

The significantly higher values $(\mathrm{p}<0.05)$ recorded for the lambs in Group 2 might be due to the higher plane of nutrition in this group $[5,43]$. The TLC values recorded in the present study agreed to the normal value as reported by Schalm et al. [17] for sheep. The values recorded in the present study were found at par with that reported for Tuj sheep $\left(7.7 \pm 1.9 \times 10^{3} / \mathrm{mm}^{3}\right)$ by Bozdogan et al. [20]. The minute difference between the leukocyte numbers found in the present study, as also reported by Bozdogan et al. [20], might be due to differences in breed, environment, nutrition and health status of the animals in the two studies. Nevertheless all the values of hematological profile remain within normal physiological limits.

\section{Serum biochemical profiles in lambs}

As far as the characterization of the energetic state of the ruminants is concerned, the glucose and the total cholesterol were evaluated. Elevated concentration of glucose and cholesterol has a close relationship with the nutritional state of the animal $[30,45]$ courtesy of subsequent stages of lactation [20,25].

On the other hand, values of rest of the biochemical parameters of Group 2 lambs showed a non-significant increase trend in their values which may be culminated due to improved milk production in ewes due to supplementary concentrate feeding $[9,38]$.

\section{Incidence of disease and mortality}

No disease or mortality was encountered in either group during the experimental period which might be due to pre-emptive deworming.

\section{Conclusion}

From the present study it can concluded that supplementation of a balanced concentrate mixture (crude protein 18.21\%)@ 200 g/ewe/day along with grazing during the first 2 months of lactation resulted in higher ewe body weight gain. It improved the hematological and metabolic profiles of the ewes. It also resulted in higher body weight gain in lambs born to the supplemented ewes and also improved their hematological and metabolic profiles.

\section{Authors' Contributions}

SSB, CRP and BP have conceived, planned and designed the study. SSB, CS and AS have conducted the research, analyzed and kept a due record of the data. Manuscript was framed and drafted by SSB, AS \& BJ under the aegis of CRP. All authors read and approved the final manuscript.

\section{Acknowledgments}

The authors are thankful to the Vice chancellor, Orissa University of Agriculture and Technology and the Dean, College of Veterinary Science and Animal 
Husbandry, Bhubaneswar for their support and cooperation in carrying out the study. The fund for the study was provided by Department of Livestock Production \& Management, College of Veterinary Science and Animal Husbandry, Orissa University of Agriculture and Technology, Bhubaneswar, Odisha.

\section{Competing I nterests}

The authors declare that they have no competing interests.

\section{References}

1. Kornel, D., Mohapatra, S.C., Alhawat, S.P.S. and Tripathy, A. (2004) Biodiversity of livestock in Orissa and its role. Papers, Proceedings and Presentations of the Workshop Held in Bhubaneswar, India, on 6th and $7^{\text {th }}$ February, 2004.

2. Coop, I.E. (1950) The effect of level of nutrition during pregnancy and during lactation on lamb and wool production of grazing sheep. J. Agric. Sci., 40(4): 311-340.

3. Chaturvedi, O.H., Mann, J.S. and Karim, S.A. (2010) Effect of concentrate supplementation to ewes grazing on community rangeland during late gestation and early lactation. Indian. J. Small. Rumin., 16(1): 97-100.

4. Snedecor, G.W. and Cochran, W.G. (1998) Statistical Methods. $6^{\text {th }}$ ed. Oxford and IBH Publishing Company, Kolkata, India.

5. Idris, A.O., Kijora C., El-Hag F.M. and Salih, A.M. (2010) Effect of supplementation on late pregnancy and early lactation of body weight of desert ewes and their lambs. Livest. Res. Rural. Dev., 22(10). Available from: http://www.lrrd. org/lrrd22/10/idri22193.htm.

6. Adrian, J.A.L. and Arancon, N.Q. (2011) Factors affecting the milk yield and composition of Rahmani and Chios sheep. Int. J. Livest. Prod., 2(3): 024-030.

7. Tibin, I.M., Salaha, S.A. and Noorb, I.A. (2010) Effect of management and feed supplementation on the reproductive performance of Hammari sheep under range conditions in North Kordofan, Sudan. Conference on International Research on Food Security, Natural Resource Management and Rural Development held in ETH Zurich, 14th to $16^{\text {th }}$ September; 2010.

8. National Research Council. (2007) Committee on Nutrient Requirements of Small Ruminants Nutrient Requirements of Small Ruminants: Sheep, Goats, Cervids, and New World Camelids. National Academy Press, Washington, D.C.

9. Jordan, M. and Hanke, H.E. (1977) Effect of level of grain fed ewes during late lactation on lamb production. J. Anim. Sci., 45(5): 945-947.

10. Osuagwah, A.I.A. and Aire, T.A. (1990) Intra uterine growth rates of the West African dwarf goats and some fetal organs in relation to strategic feed supplementation during pregnancy. J. Vet. Med., 37(3): 198-204.

11. Blunt, M.H. and Huisman, T.H.J. (1975) The haemoglobins of sheep. In: Blunt, M.H., editor. The Blood of Sheep. $1^{\text {st }}$ ed. Springer, Heidelberg, Berlin. p155-183.

12. Kramer, J.W. (2000) Normal haematology of cattle, sheep, and goat. In: Feldman, B.F., Zinkl, J.G. and Jain, N.C., editors. Schalm's Veterinary Haematology. 5th ed. Philadelphia: Lippincott Williams and Wilkins; 1075-1084.

13. Coffin, D.L. (1953) Manual of Veterinary Clinical Pathology. $3^{\text {rd }}$ ed. Comstock, Ithaca, New York., USA.

14. Holman, H.H. (1944) Studies on the haematology of sheep: I.- The blood-picture of healthy sheep. J. Comp. Pathol. Ther., 54(1): 26-40.

15. Opara, M.N., Udevi, N. and Okoli, I.C. (2010) Haematological parameters and blood chemistry of apparently healthy West African Dwarf (Wad) goats in Owerri, South Eastern Nigeria. N. Y. Sci. J., 3(8): 68-72.

16. Skotnicka, E., Muszczyński, Z. and Suska, M. (2011) Effect of the periparturient period on serum lipid and cholesterol lipoprotein concentrations in goats (Capra hircus). Acta. Vet. Hung., 59(4): 445-454.

17. Schalm, O.W., Jain, N.C. and Carroll, E.J. (1975) Veterinary Haematology. $3^{\text {rd }}$ ed. Lea and Febiger, Philadelphia.

18. Benjamin, M.M. (1985) Outline of Veterinary Clinical Pathology. $1^{\text {st }}$ ed. Kalyani Publishers, New Delhi, India.

19. Rodostits, O.M., Gay, C.C., Hinchcliff, W. and Constable, D. (2007) Veterinary Medicine, A Text Book of the Diseases of Cattle, Horses, Sheep, Pigs and Goats. $10^{\text {th }}$ ed. Saunders, W.B, London.

20. Bozdogan, O., Cenesiz, M., Kaya, M. and Kamiloglu, N. (2003) The effect of age, sex, housing system and pregnancy on some blood parameters of Tuj sheep. Turk. J. Vet. Anim. Sci., 27(3): 521-524.

21. Grunsell, C.S. (1955) Seasonal variation in the blood and bone marrow of Scottish hill sheep. J. Comp. Pathol. Ther., 65: 93-107.

22. Samardžija, M., Vince, S. and Đuričić, D. (2013) Association of parity, fecundity and body condition score with blood serum concentration of some metabolites during pre and post parturient period in German improved fawn goats. Vet. Arhiv., 83(5): 469-477.

23. O'Doherty, J.V. and Crosby, T.F. (1997) The effect of diet in late pregnancy on colostrum production and immunoglobulin absorption in sheep. Anim. Sci., 64(1): 87-96.

24. Amanlou, H., Karimi, A., Mahjoubi, E. and Milis, C. (2011) Effects of supplementation with digestible undegradable protein in late pregnancy on ewe colostrums production and lamb output to weaning. J. Anim. Physiol. Anim. Nutr., 95(5): 616-622.

25. Moallem, U., Rozov, A., Gootwine, E. and Honig, H. (2012) Plasma concentrations of key metabolites and insulin in late-pregnant ewes carrying 1 to 5 fetuses. J. Anim. Sci., 90(1): 318-324.

26. Anwar, M.M., El-Din, A.N. and Taha, T.A. (2012) Changes in some hematological and serum biochemical parameters during the first week after lambing in six consecutive parities in some Egyptian sheep breeds. Egypt. J. Anim. Prod., 49(3): 293-302.

27. Piccione, G., Caola, G., Giannetto, C., Grasso, F., Runzo, S. C., Zumbo, A. and Pennisi, P. (2009) Selected biochemical serum parameters in ewes during pregnancy, post-parturition, lactation and dry period. Anim. Sci. Pap. Rep., 27(4): 321-330.

28. Kaneko, J.J., Harvey, J.W. and Bruss, M.L. (1997) Clinical biochemistry of domestic animals. 5th ed. Academic Press, San Diego, London, Boston, New York, Sydney, Tokyo, Toronto.

29. Eshratkhah, B., Sadaghian, M., Eshratkhah, S., Pourrabbi, S. and Najafian, K. (2010) Relationship between the blood thyroid hormones and lipid profile in Moghani sheep; influence of age and sex. Comp. Clin. Pathol., 19(1): 15-20.

30. Jalilian, M.T. and Moeini, M.M. (2013) The effect of body condition score and body weight of Sanjabi ewes on immune system, productive and reproductive performance. Acta. Agric. Slov., 102(2): 99-106.

31. Fibrosas, C.T.N.D. and Condiciones, B. (2011) Metabolizable energy intake and changes in body weight and body condition of pelibuey ewes fed three levels of roughage diets under tropical conditions. Trop. Subtrop. Agroecosyst., 14(3): 777-786.

32. Finco, D.R. (1997) Kidney function. In: Kaneko, J.J., Harvey, J.W. and Bruss, M.L., editors. Clinical Biochemistry of Domestic Animals. $5^{\text {th }}$ ed. Academic Press, San Diego, London, Boston, New York, Sydney, Tokyo, Toronto. p441-484.

33. Caldeira, R.M., Almeida, M.A., Santos, C.C., Vasques, M.I. and Vaz Portugal, A. (1999) Daily variation in blood enzymes and metabolites in ewes under three levels of feed intake. Can. J. Anim. Sci., 79(2): 157-164.

34. Sakkinen, H., Stien, A., Holand, O., Hove, K., 
Eloranta, E., Saarela, S. and Ropstand, E. (2001) Plasma urea, creatinine, and urea: Creatinine ratio in reindeer (Rangifer tarandus tarandus) and in Svalbard reindeer (Rangifer tarandus platyrhynchus) during defined feeding conditions and in the field. Physiol. Biochem. Zool., 74(6): 907-916.

35. Sejian, V., Singh, A.K., Sahoo, A. and Naqvi, S.M.K. (2014) Effect of mineral mixture and antioxidant supplementation on growth, reproductive performance and adaptive capability of Malpura ewes subjected to heat stress. J. Anim. Physiol. Anim. Nutr., 98(1): 72-83.

36. Naqvi, S.M.K., Soren, N.M. and Karim, S.A. (2011) Effect of concentrate supplementation on performance, ovarian response, and some biochemical profile of Malpura ewes. Trop. Anim. Health. Prod., 43(5): 905-913.

37. Parhi, N. (2011) Productive and reproductive performance of Kendrapara sheep in their native tract, MVSc. Thesis Submitted to Orissa University of Agriculture and Technology, Bhubaneswar.

38. Galvani, D.B., Pires, C.C., Hübner, C.H., Carvalho, S. and Wommer, T.P. (2014) Growth performance and carcass traits of early-weaned lambs as affected by the nutritional regimen of lactating ewes. Small Rumin. Res., 120(1): 1-5.

39. Arnold, G.W., Wallace, S.R. and Boer, E.S. (1977) Effect of lupin grain supplements on lamb birth weight and growth rate and on milk production of Merino ewes. Aust. J. Exp. Agric. Anim. Hushbandry, 17(89): 915-919.

40. Khattab, H.A., Khattab, A.R., Abou-Ammou, F.F. and El-Sayed, H.M. (2004) Effect of natural protected protein on milk yield and its composition of sheep. Egypt. J. Nutr. Feed, 7(2): 119.

41. Kassab, A.Y., Abdel-Ghani, A.A., Solouma, G.M., Soliman, E.B. and Abd Elmoty A.K (2009) Lactation performance of Sohagi sheep as affected by feeding canola protected protein. Egypt. J. Sheep. Goat. Sci., 4(2): 65-78.

42. Flamant, J.C. and Morand-Fehr, P. (1982) Milk production in sheep and goats. In: Coop, I.E., editor. Sheep and Goat Production. Elsevier, Amsterdam. p275-295.

43. Rohilla, P.P. and Chand, K. (2004) Effect of supplemental feeding on growth of kids and milk yield of Marwari goats. Indian J. Small Rumin., 10(2): 143-146.

44. Min, B.R., Hart, S.P., Sahlu, T. and Satter, L.D. (2005) The effect of diets on milk production and composition and diets on milk production and composition and on lactation curves in pastured dairy goats. J. Dairy Sci., 88(7): 2604-2615.

45. Delavaud, C., Ferlay, A., Faulconnier, Y., Bocquier, F., Kann, G. and Chilliard, Y. (2002) Plasma leptin concentration in adult cattle: Effects of breed, adiposity, feeding level, and meal intake. J. Anim. Sci., 80(5): 1317-1328. 